\title{
Strategies of Business English Translation Teaching Based on Economic Integration
}

\author{
Hailong Li \\ Dongchang College of Liaocheng University, Liaocheng, Shandong, China, 252000
}

Keywords: economic integration; business English translation teaching; strategy

\begin{abstract}
In the environment of economic integration, the international economic exchanges and cooperation are deepening and the demands for business English translation talents are increasing. Thus, the state and society put forward higher request for business English translation teaching. Therefore, in order to improve the quality of teaching and train more high-quality business English translation talents, it is necessary to use modern teaching methods and other measures effectively in business English translation teaching.
\end{abstract}

\section{Introduction}

The main features of business English translation course, Business English is used in foreign trade business activities, and its own characteristics are profession, practice and intellect. For business English translation teaching, the main purpose is to train a large number of application-oriented talents with high professional quality, which needs more emphasis on the practicality of talent and professionalism. So, the objectives of business English translation of the course are very clear, Therefore, in the process of learning, we should pay attention to help students understand and master some basic business knowledge and a certain number of business English vocabulary and phrases, so that students can read and understand skillfully business English professional literature, business letters and foreign business contracts. However, in order to correctly understand the substance and meaning of some commercial advertising, and make timely and accurate translation or interpretation in the number of business activities or business occasions there must be stronger practical ability. Because, in many occasions to use business English and most of the foreign trade activities, the crowd that engaged in business English translation activities, not only represent individuals and enterprises, but also pay more attention to safeguarding the country's interests and dignity, to maintain the country's image and reputation. ${ }^{[1]}$

\section{The Development of Business English Translation Teaching in Economic Integration}

Business English translation is mainly about the relevant translation of the information in the business activities, for which business English professional requirements are very strict. Because, in the occasions of business English trades, most foreign trades are the cooperation and exchanges with other countries, which not only related to the interests of individual enterprises, but also related to the country's honor and interests. Therefore, the personnel engaged in business English translation must have higher professional quality and professional accomplishment as well as strong comprehensive ability. However, there are some problems in business English translation teaching, which have a certain influence on business English translation teaching.

\subsection{A serious shortage of teachers}

There is a certain difference between business English translation and other English courses. The former is a commercial nature, mainly to train business English translators in the international trade activities, Therefore, the teachers who are engaged in business English translation teaching need not only the basic knowledge of English, but also the practical skills of business knowledge and business English translation, as well as rich practical teaching experience and teaching skills, which are necessary for the teachers who are engaged in business English translation teaching. However, 
the number of colleges and universities offering business English translation teaching is very large, which results in a serious shortage of teachers in business English translation teaching. In many colleges and universities, teachers who are engaging in business English translation teaching are ordinary English teachers, most of who do not have business English translation knowledge and experiences, which leads to a number of business-related problems, which seriously affects the development of business English translation teaching and professional personnel training. ${ }^{[3]}$

\subsection{The lack of professionalism in the business English teaching materials}

At present, the teaching materials of business English translation are imperfect and lack of professional characteristics. This is mainly due to the lacks of the professionals and the experts of the commercial English translation in our country, which causes lacks of professional's instruction in the process of teaching material compiling. The present business English translation teaching materials are mostly spliced together with the different contents, which lacks of the systematic characteristic and the integrity, causing the contents and knowledge relatively narrow in the teaching material, and the similar or same content appeared repeatedly. The contents of the materials do not make a scientific and rational organization, and the whole point of knowledge on the program is relatively disorganized, which has a direct impact on the quality of teaching and learning in the business English translation. In addition, as the research of business English translation teaching is in the stage of development, various aspects research are imperfect. For example, as the foundational thing, the teaching material is mostly simple, which lacks of the deep level in the contents. On one hand, this does not favor student's growth and development, and on the other hand, it is difficult to raise the talented person and satisfy the social and market need.

\section{Strategies of Business English Translation Teaching Based on the Economic Integration}

It exists many problems in business English educational model in our country, including the teaching material, the teachers' quality and teaching level and so on which all seriously influenced the development of the business English translation teaching, and hindered the talented person's raise of commercial English translation. ${ }^{[2]}$ Therefore, it is necessary to carry out appropriate reforms and to take positive and effective measures to reform the existing modes of teaching, to promote the educational development of business English translation. The business English translation teaching strategies based on the economic integration mainly include the following aspects:

\subsection{Enhance the teachers' level in the business English translation teaching}

In business English translation teaching, it is important to improve teaching quality and level. First, the most important thing is to improve the teaching quality of teachers in business English translation. From this we can see that the quality and level of teachers plays a key role in students' growth, and only the teachers themselves reached a certain height firstly can they produce high-quality students. ${ }^{[3]}$ Under the economic integration condition, in order to satisfy the demand of society to the translation talented person of the business English, and train the large quantities of somewhat outstanding business English professional, we need to complete the construction work of the teachers troop from two aspects: First, the university may advertise for one group of talented person with specialized foreign trade work from the society, who has the high commercial English proficiency and rich specialized and commercial knowledge, as well as rich commerce working practice experiences. let the talented person hold the post of the business English translation teaching work according to the school and talented persons' actual situation. Second, training the existing teachers in their own schools.

\subsection{Correctly understand business English translation and improve the quality of teaching materials}

It exists certain differences between the business English translation and the ordinary English translation, therefore, the school must have a correct understanding and make a correct appraisal to the business English translation, and distinguish the business English translation and the 
conventional English translation. In the conventional English translation, the student may use the different glossary to express the identical meaning, However, it is polysemy for a lot of words in English, therefore, in order to avoid the defect and improve the accuracy of the translation and professional, it is necessary for the translator to own higher professional quality and translation skills.In addition, Numerous studies have found that the significance of correct understanding of business English translation teaching, which is a precondition to improve the quality of teaching.

\section{Conclusion}

Under the economic integration background, the international economical exchange deepens unceasingly, and the commercial demand for the English translation talented person increases in large scale, which puts forward new requirements and challenge for business English translation teaching in China. Therefore, the universities must have to take a series of measures to improve their own qualities and levels of teaching, and foster more high quality business English translation talented persons for society.

\section{References}

[1] Lv Wei. Economic integration and business English translation teaching [J]. Journal of education review, 2013,01:111-113.

[2] Wang Hao.Business English translation teaching problems and countermeasures [J]. Journal of seas, 2016,01:148-149.

[3] Zhang Lu. Based on the economic integration under the environment of business English translation teaching analysis [J]. Journal of exam, 2016,72: 79. 